\title{
UDC 633.62:664.134
}

\section{STORAGE TIME EFFECT ANALYSIS OF TECHNOLOGICAL AND MICROBIAL QUALITY OF SORGHUM SACCHARATUM STEM JUICE}

N. A. GRYGORENKO, Candidate of Technical Sciences, Head of the Laboratory of Molecular Genetic Polymorphism

\section{Institute of Bioenergy Crops and Sugar Beet NAAS of Ukraine \\ E-mail: grygorenko.na@gmail.com}

\begin{abstract}
Results of studies on the storage of Sorghum saccharatum stems as an industrial feedstock are presented in the paper. It is proved that physiologically mature stems of Sorghum saccharatum may be preserved for a month providing they are placed in storage without symptoms of illnesses, which allows obtaining juice without significant changes of technological and microbiological
\end{abstract}

Relevance. Processing of Sorghum saccharatum to a sugar-based product faces the problem of the organization of a constant and uniform supply of raw material. It is necessary to process sorghum raw materials of various vegetation periods of ripening. At the initial stage, there is a need to process early- and medium-ripening varieties and hybrids, and at the final stage late-ripening ones.

In addition, the length of a campaign largely depends on the possibility of storing Sorghum saccharatum stems as an industrial raw material. Rational storage of stems can be considered one of the main prolongation factors for the production season of food syrups.

There are various scientific opinions about the storage life of quality. Implementation of such storage conditions for sorghum saccharatum in the industry can significantly extend sweet sorghum campaign and reduce the price of the final product.

Keywords: Sorghum saccharatum stem, storage time, technological quality, Sorghum saccharatum juice, microbiological indicators, helminthosporiosis

Sorghum saccharatum stems. Long storage life of stems in closed shelters is preferred nowadays, but it is necessary to note the dynamics of decreasing the content of sugars. According to Ferraris and Steward [2], short-term storage of sorghum stems is also possible. Storing stems for 72 hours do not lead to the changing of dry matter and sucrose content. This point of view is also supported by Delavier [3], providing that storage within two days is possible only under normal climatic conditions without frosting.

Diversification of approaches indicates uncertainty in the changes that occur in the raw material during storage. Therefore, there are reasons to consider needs for detailed research in this field. 
Григоренко Н.О.

The purpose of the research was to identify the features of changes in technological and microbiological quality of Sorghum saccharatum juice provided that raw materials are stored within a 1 month.

To achieve the goal, both convenient and special research methods were exploited. Dry matter content of juice was determined by the refractometric method. Dry matter content of stems was determined by weighting. Total sugars of juice was determined according to the coppermetric method by Luff-Schoorl [4]. The acidity of the juice was determined by titration method in terms of lactic acid. Purity was calculated as the ratio of total sugars to the dry matter of Sorghum saccharatum juice.

The quality of Sorghum saccharatum juice was tested in terms of the following microbiological parameters: quantity of mesophilic aerobic and optional-anaerobic microorganisms (QMAFAnM), the quantity of yeast and mold, and the presence of bacteria of the coliforms group in accordance with standards [5, 6].

Samples of Sorghum saccharatum juice, obtained by pressing of crushed stems taken from storage place were analyzed. Two hybrids of Sorghum saccharatum - 'Mamont' and 'Zubr' (originated by the National Center of Seed and Nutritional Sciences) - were chosen for the experiment. Stem samples of Sorghum saccharatum were separated from the leaves and panicles and prepared in open areas, where they were stored at the temperature from 6 to $12^{\circ} \mathrm{C}$ (October 2017) for 1 month.

It should be mentioned that samples of Sorghum saccharatum stems were taken separately due to the colour markers. Leaves and stems that had brown spots were affected by helminthosporiosis (brown spot). The causative agent of the disease is the imperfect fungus Helmiri-thosporium turcicum Pass. Its mycelium initially develops in the intercellularway in the parenchymal tissue and then penetrates into the vascular system of leaves, affecting stems and interstitial. Helminthosporiosis leads to premature falling leaves, stem destruction, and, as a consequence, reduce the yield of green mass [7].

Visual examination of sorghum plants showed that plants of 'Zubr' hybrid were affected to a larger extent which is connected with a lower resistance of this hybrid to helminthosporiosis. In addition, 'Zubr' feedstock had worth quality: dry matter content in the stems equaled $31.2 \%$, dry matter content of juice $14.0 \%$, total sugar content $11.06 \%$; purity of juice 79.0\%. 'Mamont' hybrid had $25.1 \%$ dry matter content of stems, $18.2 \%$ dry matter content of juice, $16.78 \%$ total sugar content and $92.2 \%$ juice purity. Changes of technological quality and the microbiological status of sorghum juice were discovered in the process of stems storing. Stems were sampled once 


\section{Григоренко Н.О.}

a week, crushed, squeezed and the juice was analyzed in regard to the dry matter content, total sugars, acidity (by lactic acid), and microbiological parameters.

The purity of juice was also calculated.
Shown in the Tables 1-2 are the changes of technological parameters of sorghum material over storage time in shown in.

\section{Technological quality of 'Mamont' hybrid juice over storage time}

\begin{tabular}{|l|c|c|c|c|c|}
\hline $\begin{array}{c}\text { Storage } \\
\text { time } \\
\text { (days) }\end{array}$ & $\begin{array}{c}\text { Dry matter } \\
\text { content of } \\
\text { stems }(\%)\end{array}$ & $\begin{array}{c}\text { Dry matter } \\
\text { content of } \\
\text { juice }(\%)\end{array}$ & $\begin{array}{c}\text { Total sugars } \\
\text { content of juice } \\
\text { (weight } \%)\end{array}$ & $\begin{array}{c}\text { Purity } \\
(\%)\end{array}$ & $\begin{array}{c}\text { Acidity (lactic acid) } \\
\left(\mathrm{mg} / 100 \mathrm{~cm}^{3}\right)\end{array}$ \\
\hline 1 & 25.1 & 18.2 & 16.78 & 92.20 & 194.4 \\
\hline 6 & 27.5 & 18.4 & 16.72 & 90.87 & 201.8 \\
\hline 12 & 28.4 & 18.6 & 16.61 & 89.30 & 248.4 \\
\hline 18 & 29.5 & 19.0 & 16.59 & 87.31 & 252.0 \\
\hline 24 & 30.6 & 19.6 & 16.49 & 84.13 & 272.0 \\
\hline 30 & 32.5 & 19.8 & 16.36 & 82.63 & 302.0 \\
\hline
\end{tabular}

\section{Technological quality of 'Zubr' hybrid juice over storage time}

\begin{tabular}{|l|c|c|c|c|c|}
\hline $\begin{array}{c}\text { Storage } \\
\text { time } \\
\text { (days) }\end{array}$ & $\begin{array}{c}\text { Dry matter } \\
\text { content of } \\
\text { stems }(\%)\end{array}$ & $\begin{array}{c}\text { Dry matter } \\
\text { content of } \\
\text { juice }(\%)\end{array}$ & $\begin{array}{c}\text { Total sugars } \\
\text { content of juice } \\
\text { (weight } \%)\end{array}$ & $\begin{array}{c}\text { Purity } \\
(\%)\end{array}$ & $\begin{array}{c}\text { Acidity (lactic acid) } \\
\left(\mathrm{mg} / 100 \mathrm{~cm}^{3}\right)\end{array}$ \\
\hline 1 & 31.2 & 14.0 & 11.06 & 79.00 & 363.3 \\
\hline 6 & 32.6 & 13.6 & 9.88 & 72.70 & 496.8 \\
\hline 12 & 36.0 & $11.6^{*}$ & 8.11 & 70.00 & 663.3 \\
\hline
\end{tabular}

Table 1 data analysis shows that the quality of the stems of 'Mamont' hybrid varies during storage for 30 days. There are no significant changes in the dynamics of deterioration of the technological quality of juice in the process of stems storing, which indicates a high stability of this hybrid to the pathogen of brown spot disease. However, there is an increasing of dry matter content of stems, which is connected with moisture evaporation. In addition, an increase in the total sugars and organic acids content is noted in permissible limits, which was fixed by increasing the titrated acidity in terms of lactic acid. This is connected with the spending of carbohydrates on living processes. Therefore, the amount of carbohydrates reduced with storing, and as a consequence, the purity of juice decreased. However, these changes are not so significant for further technological processing of stems for food and technical purposes. It can also be successfully used in sugar factories or small processing plants of the food industry (depending on the volumes of processed sorghum feedstock) for the production of food syrup by the developed technology [8].

At the same time, storage of 'Zubr' stems (Table 2) significantly degrades their technological quality, which is 


\section{Григоренко Н.О.}

connected with a significant damage, caused by helminthosporiosis. This is confirmed by increasing juice acidity in terms of lactic acid, which indicates an intensive decomposition of sugars to organic acids and, as a consequence, decreasing the purity of juice.

According to visual observations, the causative agent of the disease enters the stem core through leaves on the $12^{\text {th }}$ day of 'Zubr' stems storage, then spreads and affects juice. Irreversible processes of decomposition of sugars into organic acids occur in sorghum juice, as well as the formation of coloured substances of melanoidins [9]. All these negative consequences make juice unsuitable for further processing in the food industry.

The results of microbiological parameters of sorghum juice over the storage time (Tables 3-4) conform to previous studies. Thus, regular changes in microbiological parameters of sorghum juice correlate with the concentration of sugar. In particular, it can be seen from Tables 3-4. A gradual decrease in the content of sugars in sorghum juice leads to a decrease of mesophilic aerobic and optional anaerobic microorganisms, yeast and mold from $4.3 \times 10^{6}$ to $1.8 \times 10^{5} \mathrm{CFU}$ and from $2.4 \times 10^{4}$ to $3.0 \times 10^{3} \mathrm{CFU}$, respectively. The quantity of coliform bacteria remained at the same level during the storage of juice, namely, $0.001 \mathrm{~cm}^{3}$. Such a tendency can be explained by the fact that carbohydrates are the main source of vital activity of microorganisms and changing concentration of carbohydrates in juice leads to concentration changes of microorganisms.

\section{Microbiological parameters of 'Mamont' hybrid juice over storage time}

\begin{tabular}{|l|c|c|c|}
\hline $\begin{array}{c}\text { Storage time } \\
\text { (days) }\end{array}$ & $\begin{array}{c}\text { QMAFAnM } \\
\left(\mathrm{CFU} / \mathrm{cm}^{3}\right)\end{array}$ & $\begin{array}{c}\text { Yeast and mould } \\
\left(\mathrm{CFU} / \mathrm{cm}^{3}\right)\end{array}$ & $\begin{array}{c}\text { Bacteria of the E. coli group } \\
\left(\mathrm{CFU} / \mathrm{cm}^{3}\right)\end{array}$ \\
\hline 1 & $2.6 \times 10^{5}$ & $1.3 \times 10^{3}$ & 0.001 \\
\hline 6 & $4.3 \times 10^{6}$ & $2.4 \times 10^{4}$ & 0.001 \\
\hline 12 & $1.6 \times 10^{6}$ & $7.0 \times 10^{4}$ & 0.001 \\
\hline 18 & $8.0 \times 10^{5}$ & $2.1 \times 10^{3}$ & 0.001 \\
\hline 24 & $1.8 \times 10^{5}$ & $3.0 \times 10^{3}$ & 0.001 \\
\hline 30 & $3.1 \times 10^{5}$ & $6.0 \times 10^{3}$ & 0.001 \\
\hline
\end{tabular}

4. Microbiological parameters of 'Zubr' hybrid juice over storage time

\begin{tabular}{|l|c|c|c|}
\hline $\begin{array}{c}\text { Storage time } \\
\text { (days) }\end{array}$ & $\begin{array}{c}\text { QMAFAnM } \\
\left(\mathrm{CFU} / \mathrm{cm}^{3}\right)\end{array}$ & $\begin{array}{c}\text { Yeast and mould } \\
\left(\mathrm{CFU} / \mathrm{cm}^{3}\right)\end{array}$ & $\begin{array}{c}\text { Bacteria of the E. coli group } \\
\left(\mathrm{CFU} / \mathrm{cm}^{3}\right)\end{array}$ \\
\hline 1 & $1.9 \times 10^{5}$ & $1.5 \times 10^{3}$ & 0.001 \\
\hline 6 & $1.7 \times 10^{6}$ & $1.1 \times 10^{4}$ & 0.001 \\
\hline 12 & $7.2 \times 10^{5}$ & $7.0 \times 10^{4}$ & 0.001 \\
\hline
\end{tabular}

\section{Conclusions}

As a result of the research, it can be stated that the stems of a highyielding 'Mamont' hybrid are resistant to diseases and can be stored for 30 days without significant changes in technological and microbiological parameters of juice. As the trend of 
Григоренко Н.О.

moisture evaporation and sugar decomposition will continue, the longer storage time is not appropriate and will lead to a deterioration of the quality of obtained juice. This will negatively affect the process of further processing. Under the conditions of putting stems

\section{References}

1. Mengoni, O. (1976). Sorgo zuccherino e I suoi sciroppi. Lindustria saccarifera italiana Italy, 69(1), 5-10.

2. Ferraris, R., Steward, G. (1979) The use of sugar sorghum as a raw material for the production of sugar. Journal Australian Institute Agricultural Science, 45(3), 156-164.

3. Delavier, (1970). Sorghum für die Zuckerproduktion. Z.f.d. Zucekind, 20(12). 640-641.

4. Kupchik, M. P., Reva, L. P., Stangeeva, N.I. (2007). Tehnologiya cukristih rechovin. Laboratornij praktikum [Technology of sugary substances. Laboratory workshop]. Kiev: NUTH, 215.

5. Cukor. Metodi viznachannya mikrobiologichnih pokaznikiv. (2007). [Sugar. Methods for the determination of microbiological indicators]. DSTU 4323:2004. Ukraine.

ДОСЛІДЖЕННЯ ВПЛИВУ ТЕРМІНУ ЗБЕРІГАННЯ СТЕБЕЛ НА ПОКАЗНИКИ ТЕХНОЛОГІЧНОЇ ТА МІКРОБІОЛОГІЧНОЇ ЯКОСТІ СОКУ СОРГО ЦУКРОВОГО

\section{Н. О. Григоренко}

Анотація. B cmammi представлені результати досліджень щчодо зберігання стебел for prolonged storage, it is obligatory to remove plants affected by Helmirithosporium turcicum Pass. During vegetation, it is necessary to apply fungicides allowed to use in Ukraine at the first signs of disease.

6. Produkti harchovi. Metodi viyavlennya ta viznachennya kilkosti bakterij vidu Escherichia coli (2001). [Food products. The methods for determining the number of bacteria of the species Escherichia coli] DSTU GOST 30726, IDT. Ukraine.

7. Skorij, V. M. (2009). Energetichni roslini v Ukraine [Energy plants in Ukraine]. Feniks, 224.

8. Grigorenko, N.O., Shtangeyev, V.O., Homichak, L.M., Grinenko. I.G. (2016). Shlyahi poshuku rozshirennya asortimentu produkciyi cukrovoyi galuzi Ukrayini [Ways of searching for expansion of the assortment of products of the sugar industry of Ukraine]. Sugar Ukraine, 6-7(126-127), 41-44.

9. Bobrovnik, L.D. (1994). Fizikohimichni osnovi ochistki u cukrovomu virobnictvi [Physico-chemical basis of purification in sugar production]. Naukova dumka, 255.

сорго иукрового як промислової сировини. Встановлено, щчо фізіологічно зрілі стебла сорго зберігаються протягом місяия, за умов закладання $\ddot{x}$ без ознак враження хворобами, ие дозволяє отримати сік без суттєвих змін показників технологічної та мікробіологічної якості. Впровадження умов зберігання стебел сорго иукрового у 


\section{Григоренко Н.О.}

промислових масштабах суттево розиирить термін виробничого сезону з переробки даної сировини та здешевить вартість кінцевого цукровмісного продукту

Ключові слова: цукрове сорго, термін зберігання стебел, технологічна якість, сік сорго, мікробіологічні показники, хвороба, гельмінтоспоріоз.

\section{ИССЛЕДОВАНИЕ ВЛИЯНИЯ}

СРОКА ХРАНЕНИЯ СТЕБЛЕЙ

$$
\text { НА ПОКАЗАТЕЛИ }
$$

ТЕХНОЛОГИЧЕСКОГО И

МИКРОБИОЛОГИЧЕСКОГО

КАЧЕСТВА СОКА СОГРО

\section{САХАРНОГО}

\section{Н.А. Григоренко}

Аннотация. B cmaтье представлень результаты исследований по хранению стеблей сорго сахарного как промышленного сырья. Установлено, что физиологически зрелье стебли сорго сохраняются в течение месяиа, в условиях закладки их без признаков поражения болезнями, это позволяет получить сок без существенных изменений показателей технологического $u$ микробиологического качества. Внедрение условий хранения стеблей сорго сахарного в промышленных масштабах существенно расширит срок производственного сезона по переработке данного сырья и удешевит стоимость конечного сахаросодержащего продукта

\section{Ключевые слова: сахарное} сорго, срок хранения стеблей, технологическое качество, сок сорго, микробиологические показатели, болезнь, гельминтоспориоз 